\title{
Legislation, Ethics, and Religion: An Approach in the Context of Religious Freedom
}

\author{
Ivan Vasile Ivanoff
}

\begin{abstract}
The analysis of the concepts present in the title has been made by taking into account the prevalence of some over the others and in strong inter-dependence between them, while the practical effect of the conclusions drawn is the relevant one. KEY WORDS: morality, ethics, legislation, religion, interdependence
\end{abstract}

$\mathrm{T}$ he presentation of the themes debated in the context of religious freedom constitutes, in my opinion, a subject for intellectual analysis and reflection, with a particular tone of pragmatic significance. The co-existence of a human being together with other human beings in a social, political, cultural, economic and religious environment involves rules and habits which shape the social, cultural, moral and religious behavior.

Considering a brief appeal to terminological interconnectedness between the concepts legislation, ${ }^{1}$ ethics, ${ }^{2}$ and religion, ${ }^{3}$ my goal is to establish a symbiotic link of connection or determination, which will be analyzed both from a theoretical and philosophical perspective, as well as from their pragmatic role.

One rhetorical question still remains unavoidable. Is it possible for a person to know all the laws and the moral and religious norms so as to respect them and for these concepts to determine that 
person to adopt adequate social and moral patterns of behavior for a civilized living?

What is it that makes us decent and socially integrated according to the moral norms? How can we have an adequate social and moral behavior? Does each citizen of a state know all the normative acts adopted by that state, so as to be able to respect them, given the Latin saying "nemo legem ignorare censetur" (nobody can be presumed not to know the law)? Realistically speaking, this expectation is at least utopic!

During his last speech at the Romanian Parliament, the President of Romania stated: "Romanians wish for clearer and simpler legislative norms, which do not change overnight. This reality must receive an answer. Currently fourteen thousand laws and ordinances are in force."4 From a biological perspective, reading and remembering such a great amount of normative acts, so as to be observed and applied by the citizens, is an unrealistic expectation! In this context, we are asking ourselves how is it that citizens manage not to become criminals, while the state does not become an imaginary "large prison"? What is it that defends these citizens from such qualifications?

By observing the social environment and working in the field of the law enforcement, I can say with a high degree of certainty that both the education received in family and school, as well as the social-religious morality, constitute in fact the "compass" which indicates to citizens the path they have to follow in society, avoiding or respecting the legal norms adopted by that state. It is obvious that, in the absence of a moral-religious educational component which constitutes, in fact, the basic element of the social existence, the wish for legal norms would be only a form deprived of content, while the social, economic, legal and cultural consequences would be a disaster!

What do we want to prove with the observation above? We want to point out the prevalence of the moral and religious factor in determining the social behavior of the individuals composing a society.

In a study made regarding public functions, ${ }^{5}$ with reference to the conduct of civil servants, we have reached an interesting 
conclusion regarding the correlation established between the moral and legal norms, advancing the thesis of the moral and law symbiosis and of the mutual exchange of the role of means and purpose 6 pointing out that, many of the times, the legal norms represent a means, a vector for accomplishing a moral purpose, or the other way round, when the moral expressions and values are used by the lawmaker to provide a legal, compulsory, purpose, with a general coverage.

Thus, the existence itself of the deontological and ethical codes represents a confirmation of the thesis above, mentioning that only the deontological codes are adopted by the lawmaker, while the ethical ones are assumed by various organizational and civil forms belonging to certain categories of functions, jobs and professions. Even the definition of the public function deontology, for instance, represents a symbiosis of the legal and moral norms related to the public function, which creates an image of the professional and private behavior of a civil servant. It is like in the Chinese philosophy, where Yin cannot exist without Yang and the other way round.

The co-existence and the connection of the themes debated by this paper can continue only by using the same method of observing the moral, cultural and religious phenomena. Therefore, often it is the same complex system of social relations that is regulated by spiritual norms and values. For instance, theft, murder and other crimes incriminated by the laws of Moses from the Old Testament are also incriminated by the system of moral norms, but also of the legal ones.

Religion "sanctions" the thought and the word, making the distinction between various sins; some of which can be forgiven, while others cannot. The same acts are punished by the civil law and by the social moral rules. If the sin of theft can be forgiven by religion in certain conditions, as well by the law, such as in the case of pardon or amnesty in the criminal law, moral consciousness never forgets such deeds and the public repudiation of such acts persist for entire generations.

The European space of the geopolitical existence of our country is undoubtedly impregnated with the Jewish-Christian morality. Consequently, the Christian religion was a determinant 
component for the morality and law. In fact, moral norms and ethical standards are based on the religious determination. Even the social pre-Christian behavior from this space (taking into account the Dacian period) were supported by religious statements, there being a merging between religion, law and morality. The entire feudal period of the Romanian states was determined by the prevalence of religion over the other two social components, so that it was only when the modern contemporary states emerged that a distinction was made between the components; nonetheless, there is even today an inter-dependence between them. Only a simultaneous and inter-disciplinary analysis of this co-existence can succeed and it has a practical use for the society. In our opinion, the constitutional laity of modern and democratic states separate only formally the components mentioned above, but the practical reality regarding the functioning of the states makes nothing but confirming the merging of the systems analyzed. A simple example proves this assertion. Thus, the oath sworn by the civil servants and officers on the occasion on their investment with the public function refers to the three components. We are speaking first of all of a legal text upholding the existence of the oath and the compulsory character of it being sworn. In the context of the oath, a clear reference is made to the respect for constitution and law, while the exertion of these functions must be made in good faith, a component which is related to the ethics and morality! The guarantee for respecting the oath is given, in the end, by the reference to the Divinity as an additional argument to strengthen the legal statement of the expression! This situation occurs in front of the court, when the oath sworn by the witness is strengthened and guaranteed too by the appeal to the Divinity.

On the other hand, it can be noticed that we have earned a lot in the freedom field but, at the same time, we have also lost a lot in the moral field. Which is the loss and what generated this predicament? On the one hand it was natural for the social expectations of human beings, denied for so many decades, to reach peaks so high and impossible to reach from a human perspective by the state leadership structures. As a rule, any illusion is followed by a potential disillusion! Besides the generic aspects of the concepts erosion, the 
fears of the prominent economist Anghel Rugină ${ }^{7}$ came true at the beginning of the 1990s, when he sadly stated that, "instead of taking the best from the communism and build the best of capitalism over it, we have taken over the worst of the communism and built the worst of capitalism over it."8 The result of this poisonous "symbiosis" was the erosion of the freedom concept and the destruction of the moral being of the Romanian people.

Unfortunately, the communist period in which the human freedom was denied led to the uncontrolled manifestation of it, so that most of the people understood that they could do whatever they wished without having to account to anyone or care about the freedom of the others. In this social frenzy, strong characters, deprived of morality or social principles, took over the political, economic and social mechanisms, impregnating this kind of abnormal behavior at a decisional level. We have reached the point where, in 2016 several concepts constructing and defining the human being (goodness, good will, modesty, altruism, common sense, sensibility and so on) became genuine handicaps when it came to social integration, as they are considered true weaknesses of the human being and even mocked at. This reversal of human values took place quite fast, during the historic time, so that cheap tastes, rudeness, recklessness, selfishness, guts, the lack of respect and education have become the "genuine" values of the parvenus, who managed to climb higher and higher the Romanian social leather.

The eternal elements which have supported the existence of the Romanian people are starting to be placed aside, in the shadow and forgiveness, by being replaced with "tumor" which contaminates the social body.

We are speaking here about traditions which have started to be forgotten, like popular crafting, old workmanship, authentic culture and so on, by being replaced with contemporary creations (for instance cheap easy music), imported products, broadcasted subculture and tabloids.

The structural bases of the religions are under attack, as denigration is promoted against church leaders and the reference elements of the Christian religion are questioned, by invoking all sorts of scientific discoveries which presumably deny the divine 
character of the Saint Trinity for instance, according to the principle: "Beat up the shepherd and destroy his herd."

It can be currently noticed that the personal freedom has been taken so far that the abortion is now considered legal and moral. Is it however accepted by the religion? As far as we know, all recognized religions and cults condemn this method, and yet law, despite the morality above, still allows for the abortion, ignoring the religious opposition. It is an obvious contradiction between high structural concepts. The misinterpretation of freedom has led to this dangerous process as we see it, which continues to expand. The freedom of movement, determined by the lack of efficiency of the national offer, has led to the break of certain secular connections within the family, so that the word "together"-which should characterize a family - has become something else! The family - "the basic cell of the society," as it was considered during communism-has become the most vulnerable in front of the external attacks of all types. The moral promiscuity, the media, economic problems, poor education and behavioral decadence, as an expression of a misinterpreted freedom, have irreversibly destroyed the Romanian family. The relationships outside marriage, the divorce and the consensual unions have started to become a substitute for the classical family recognized by the Christian religion and morality, being more and more approved by the law and morality. This is the second strong breach in the main chain, between its elements.

Is this the consequence of the freedom earned with such difficulty? Giving up to some sovereign prerogatives of the Romanian State, to the benefit of supranational institutions, has led to the implementation in the Romanian legislation of several regulations which are alien to the Romanian spirit, like sexual freedom, so that certain restrictive regulations belonging to the communist criminal law have been rehabilitated towards new concepts and modalities. If at the legislative level there is an obvious open-mindedness, at the moral level there are still certain reactions becoming weaker and weaker as time goes by. Consequently, this time too, religion becomes the last defense wall attempting to support certain moral-Christian concepts. And this is how it can be noticed another breach in determining the supranational elements in the Romanian society. 
As a result, it can be seen that the globalization to which we have referred brings foreign ideas and concepts in the Romanian society, which are becoming more and more predominant and which will de-personalize our national human being. We refuse to accept his type of globalization as it dissolves the national shade which characterizes us in the multinational picture.

The European integration has been understood as "Unity in diversity" and by no means as a melting of our national identity, for long supported by religion, morality and legislation. It can be noticed how all the national defense walls collapse step by step in front of the globalization storm and European federalization more and more desired.

The first "defense wall" which is under attack is the national legislation, which must be adapted to the European constitutive treaties. This leads to a gradual loss of all features of the national sovereignty, under the helpless eyes of the citizen. The second "defense wall," is the national moral standards; a cultural feature which is deeply altered by the current crisis of values.

The reversal of moral values referred to above, the excessive tolerance towards the "imports" of foreign values (i.e., Valentine's Day, Halloween), led to the irreversible alteration of the national being, melting national values in the pot of the international "values".

Religion, the last defense wall, is starting to be fiercely attacked! Gospels not approved by the Church are being discovered, traditions dating back several centuries are being questioned and church leaders are being placed under doubt, so that, little by little and in a certain way, the idea of the world ecumenism and church is starting to gain more and more dominance.

In the Islamic fundamentalist states under the religious influence of the Koran, the moral and legal concepts are being mistaken with the religious ones, so that the overlap of these types of norms is the basic rule for the functioning of the society.

We consider that in the present, in the context of the massive migration experienced by Europe, the theme in question is very applicable ${ }^{10}$. The European population is divided between two completely different opinions: one towards accepting the 
phenomenon and the other towards rejecting it; the pros and cons are related to religion, morality or legislation. Forcing an opinion over the other does nothing but radicalizing the peoples that are opposed to the phenomenon, leading to stronger nationalist and radical movements in the countries affected. Not understanding the phenomenon, not analyzing its cause, but also imposing by force a directive over the will of the peoples is, in our opinion, the worst decision which the European officials can make! The analysis of the legal, religious and ethical aspects must be completed with the geopolitical and economic aspects, whereas the practical answer to this issue can only be offered by a dialogue between the persons called to guide the destiny of the peoples. It is the reason for which we consider that the current debate of the ethical, legal and religious phenomena, in the context of the religious freedom, must go over the sphere of the theoretical analysis, into the practical daily reality, while the Olympic and academic debate of the interaction between the analyzed components must also offer practical solutions, which can afterwards be made available to the political officials. The melting pot of ideas and debates must also include a practical component, because the reality that we live in imposes solid and immediate solutions.

NOTES

${ }^{1}$ Legislation, legislations, noun. all the laws of a country or of a legal domain-from French législation, Lat. legislatio.

2 Ethics, noun 1. The theoretical study of the basic principles and conceptions from any field and of the practical thought and activity 2 . The complex of norms in relation to which a human group regulates its own behaviour, in order to make a distinction between what it is legitimate and acceptable for accomplishing goals; morality-from French éthique, Lat. ethicus.

${ }^{3}$ Religion, religions, noun 1 . Ideas, feelings and actions shared by a group, which provide to its members a worship object, a behavioral code, and a reference frame for entering in a relation with the group and the universe; confession; faith. Fig. Creed, cult. 2. Subject taught in school, aiming to educate and instruct pupils in the spirit of the given religion- From French religion, Lat. religio, -onis, Germ. religion. 
${ }^{4}$ Cf. http://www.amosnews.ro/klaus-iohannis-discurs-parlament-201509-16 (Last accessed on April 15, 2016.)

${ }^{5}$ Ivanoff Ivan Vasile, Deontologia funcției publice, $4^{\text {th }}$ ed., revised and updated, (Târgovişte: Editura Bibliotheca, 2013.)

${ }^{6}$ Ibid., 53.

${ }^{7}$ Anghel Rugină (born on May 24, 1913 in Vizurești village, Galați districtdeceased on 15 ${ }^{\text {th }}$ December 15, 2008 in the USA) was an American economist of Romanian origins, elected as honorary member of the Romanian Academy (in 1990). Cf. http://www.wikipedia.org (Last accessed on April 15, 2016.)

${ }^{8}$ Statement made by Anghel Rugină in the Florentine Hall of the town hall of Târgovişte în the 1990s, on the occasion of a visit made in the city.

${ }^{9}$ Mathew 14.31

${ }^{10}$ Cf. Samuel Phillips Hungtington, Ciocnirea civilizațiilor şi refacerea ordinii mondiale, (București: Editura Antet, 2007.) 